\title{
ANALISIS PENERAPAN AKUNTANSI LINGKUNGAN TERHADAP BIAYA OPERASIONAL PENGELOLAHAN LIMBAH PADA RUMAH SAKIT PANCARAN KASIH MANADO
}

\author{
Aldy V. J Ratulangi ${ }^{1}$, Sifrid Pangemanan ${ }^{2}$, Victorina Tirayoh ${ }^{3}$ \\ 1,2,3 Jurusan Akuntansi, Fakultas Ekonomi dan Bisnis, Universitas Sam Ratulangi, Jl. Kampus Bahu, Manado, \\ 95115, Indonesia \\ E-mail :Aldyratulangi@gmail.com
}

\begin{abstract}
The hospital is an institution engaged in the field of health, where the service provided by doctors, nurses and health experts. In its activities, hospitals use medical devices mostly made of materials that are difficult to decompose. These medical devices, when finished are used to be waste, and waste from the hospital could potentially transmit the disease. Therefore, hospitals must have a guideline on the cost of waste management, so that the existing waste can be managed properly. Environmental Accounting is present as a guide on waste management costs that can be used in waste management. The purpose of this research is to know whether GMIM Manado Pancaran Kasih Hospital has applied environmental accounting according to existing standard. The results of this study found that GMIM Pancaran Kasih Hospital has applied its environmental accounting and carried out the process of Recognition, Measurement, Recording, Presentation, and Disclosure as well as those described in Government Accounting Standards of 2010.
\end{abstract}

Keywords: Environmental accounting, Costs

\section{PENDAHULUAN}

Rumah sakit adalah sebuah perusahaan jasa yang sangan di perlukan untuk kelangsungan hidup manusia yang mana manusia itu sendiri sewaktu-waktu dapat terserang penyakit, artinya kebutuhan akan pengobatan tidak dapat kita duga-duga dan sangat di butuhkan. Namun hendaknya suatu rumah sakit benar-benar menjaga lingkungannya. Dengan cara mengelola limbahnya dengan sebaik mungkin untuk mencegah agar tidak membahayakan lingkungan di sekitarnya, apalagi limbah dari rumah sakit bisa berpotensi menularkan penyakit. Tidak hanya untuk kelangsungan rumah sakit itu sendiri tapi juga untuk kelangsungan hidup makhluk di sekitarnya baik itu tumbuhan, hewan dan juga manusia. Tahun 2009 pemerintah menerbitkan UU No 32/2009 pasal 2 yang mengatur bahwa perlindungan dan pengelolahan lingkungan hidup di laksanakan berdasarkan asas partisipatif dan kearifan lokal. Artinya undang- undang tersebut mengemukakan bahwa di perintahkan untuk menjaga, melindungi dan merawat lingkungan di sekitar.

Badan Pengawas Pasar Modal (Bapepam) juga sepertinya mendukung akan hal itu. Bapepam mengeluarkan peraturan nomor X.K.6 tentang kewajiban penyampaian laporan tahunan bagi emiten dan perusahaan publik, dimana salah satu poinnya mencakup tentang tanggung jawab sosial perusahaan yang isinya tentang lingkungan hidup seperti sistem pengelolahan limbah perusahaa (Harry, 2012). Bapepam juga bekerja sama dengan Bank Indonesia (BI) dalam memberikan kebijakan-kebijakan yang berkaitan dengan lingkungan. BI mengaitkan putusan pemberian pinjaman atau bantuan kepada perusahaan dengan persayaratan analisis dampak lingkungannya (Amdal). Sedangkan Bapepam mensyaratkan akurasi informasi Amdal kepada perusahaan yang akan go public.

Saat ini di Indonesia pengungkapan mengenai akuntansi lingkungan masih belum diatur secara khusus dalam standar akuntansi, artinya pelaporan informasi lingkungan 
dalam laporan tahunan perusahan masih bersifat sukarela. Akan tetapi IAI menjelaskan bahwa laporan tahunan harus mengakomodasi kepentingan para pengambil keputusan (Hadi, 2012:15). Dijelaskan dalam PSAK No. 1 Tahun 2014, paragraf sembilan (9) yang menyatakan : Perusahaan dapat pula menyajikan laporan tambahan seperti laporan mengenai lingkungan hidup dan laporan nilai tambah (value added statement), khususnya bagi industri dimana faktor-faktor lingkungan hidup memegang peranan penting dan bagi industri yang menganggap pegawai sebagai kelompok pengguna laporan yang memegang peranan penting. Begitupun jika instansi pemerintahan yang berpotensi dapat menghasilkan limbah, pada PSAP No. 1 Tahun 2010 di jelaskan bahwa perusahaan dapat pula menyajikan laporan tambahan seperti penyajian laporan tentang lingkungan hidup termasuk juga biaya pengelolahan limbah di dalamnya.

Akuntansi lingkungan adalah suatu ilmu akuntansi yang menunjukkan biaya riil atas input dan proses bisnis serta memastikan adanya efisiensi biaya, selain itu juga dapat digunakan untuk mengukur biaya kualitas dan jasa. Tujuan utamanya adalah dipatuhinya perundangan perlindungan lingkungan untuk menemukan efisiensi yang mengurangi dampak lingkungan. Akuntansi lingkungan pada dasarnya menuntut kesadaran penuh perusahaan-perusahaan atau organisasi lainnya yang mengambil manfaat dari lingkungan. Manfaat yang diambil ternyata telah berdampak pada maju dan berkembangnya bisnis perusahaan. Oleh karena itu penting bagi perusahaan- perusahaan atau organisasi lainnya agar dapat meningkatkan usaha dalam mempertimbangkan konservasi lingkungan secara berkelanjutan (Ikhsan, 2008:11). Namun dalam praktiknya, banyak sekali perusahaanperusahaan ataupun instansi pemerintahan seperti rumah sakit yang sepertinya belum efektif dalam menerapkan akuntansi lingkungan itu sendiri. Disadari atau tidak, kebanyakan dari perusahaan-perusahaan tersebut menyampingkan resiko kerusakan lingkungan dan mengutamakan tingkat pembangunannya.

Jika itu sudah terjadi dan limbah produksi suatu perusahaan tidak bisa di kelolah dengan baik oleh pihak perusahaan, maka nantinya pasti akan merusak lingkungan di sekitarnya apalagi jika limbah tersebut mengandung zat-zat berbahaya bagi makhluk hidup. Bagi pihak perusahaan, ini sangatlah penting. Dimana pihak perusahaan harus mengelola terlebih dahulu limbah-limbah yang mengandung zat-zat berbahaya itu sebelum membuangnya agar tidak mencemari dan tidak membahayakan lingkungan di sekitar perusahaan beroperasi. Sebagai bentuk tanggung jawab perusahaan dalam mengatasi masalah limbah hasil operasional perusahaan dengan cara melakukan pengelolaan limbah operasional perusahaan tersebut dengan cara sistematis melalui proses yang memerlukan biaya yang khusus sehingga perusahaan melakukan pengalokasian nilai biaya tersebut dalam pencatatan keuangan perusahaannya.

Di Indonesia, permasalahan lingkungan merupakan faktor penting yang harus segera dipikirkan mengingat dampak dari buruknya pengelolaan lingkungan semakin nyata saat ini. Pemilihan masalah lingkungan dalam penelitian ini di karenakan berhubungan langsung dengan makhluk hidup terutama manusia. Dimana cepat atau lambat jika lingkungan kita sudah tercemari maka manusia akan merasakan dampak negatifnya. Manusia sendiri baik disadari atau tidak mereka terlibat dalam pencemaran lingkungan itu, dan perusahaan manufaktur adalah penyumbang terbesar bagi pencemaran lingkungan. Perusahaan yang serius menanggapi permasalahan lingkungan tidak hanya menempelkan slogan bebas polusi tetapi juga menerapkan dalam sistem akuntansi. Dengan adanya pelaporan masalah lingkungan hidup, maka seluruh transaksi yang terjadi dalam suatu perusahaan dapat dikomunikasikan dengan pemakainya guna pertimbangan ekonomi dan keputusan investasi yang rasional (Hadi, 2012).

Setelah di lakukannya observasi pendahuluan yang di lakukan oleh peneliti, faktanya tidak semua rumah sakit mempunyai tempat untuk pengelolahan limbah sendiri. Hanya 
beberapa rumah sakit di kota Manado yang ada pengelolahan limbah medis dan salah satunya adalah pada Rumah Sakit Pancaran Kasih. Rumah sakit milik Swasta ini tampaknya sudah menerapkan pengelolahan limbahanya sendiri. Dengan adanya proses pengelolahan limbah tersebut tentunya akan menghasilkan biaya-biaya yang nantinya akan di keluarkan oleh pihak rumah sakit untuk mengelola limbah itu. Lokasi dari Rumah Sakit Pancaran Kasih itu sendiri yang berada di tengah-tengah pemukiman padat penduduk juga dapat membahayakan lingkungan di sekitarnya jika pengelolahan limbahnya tidak di kelola sebaik mungkin mengingat limbah yang di hasilkan rumah sakit adalah limbah B3 baik itu limbah cair maupun limbah padat yang dapat membahayakan lingkungan di sekitarnya.

\section{TINJAUAN PUSTAKA}

\subsection{Pengertian Akuntansi Lingkungan}

Menurut Kerangka Dasar Penyusunan dan Penyajian Laporan Keuangan Standar Akuntansi Keuangan menyatakan bahwa tujuan laporan keuangan adalah menyediakan informasi yang menyankut posisi keuangan, kinerja serta perubahan posisi keuangan suatu perusahaanyang bermanfaat bagi sejumlah besar pemakai dalam mengambil keputusan ekonomi (IAI, paragraf 12, 2009). Sedangkan lingkungan hidup berdasarkan Undangundang Nomor 32 Tahun 2009 Pasal 1 angka 1 adalah : "kesatuan ruang dengan semua benda, daya, keadaan dan makhluk hidup, termasuk di dalamnya manusia dan perilakunya yang mempengaruhi kelangsungan peri kehidupan dan kesejahteraan manusia dan makhluk hidup lainnya".

Dari pendapat yang lain (ikhsan, 2008:3 Akuntansi lingkungan adalah identifikasi, pengukuran dan alokasi biaya-biaya ke dalam pengambilan keputusan usaha serta mengkomunikasikan hasilnya kepada stockholders perusahaan Akuntansi lingkungan (Environmental Accounting) adalah istilah yang berkaitan dengan dimasukanya biaya lingkungan (environmental costs) ke dalam praktek akuntansi perusahaan atau lembaga pemerintah. Biaya lingkungan adalah dampak (impact) baik moneter maupun non-moneter yang harus dipikul sebagai akibat dari kegiatan yang mempengaruhi kualitas lingkungan

Dalam himpunan istilah lingkungan untuk manajemen (Solihin,2009) pengertianakuntansi lingkungan dikemukakan secara rinci bahwa akuntansi lingkungan merupakan proses accounting yang mengenali, mencari dan kemudian mengurangi efekefek lingkungan negatif dari pelaksanaan praktek laporan yang konvensional, mengenali secara terpisah biaya-biaya dan penghasilan yang berhubungan dengan lingkungan dalam system laporan yang konvensional, mengambil langkah-langkah aktif untuk menyusun inisiatif-inisiatif untuk memperbaikiefek-efek lingkungan yang timbul dari praktek-praktek pelaporan konvensional, merencanakan bentuk- bentuk baru system laporan financial dan nonfinansial system informasi dan system pengawasan untuk lebih mendukung keputusan manajemen yang secara lingkungan tidak berbahaya. Mengembangkan bentuk-bentuk baru dalam pengukuran kinerja, pelaporan dan penilaian untuk tujuan internal dan eksternal.Mengenali, menguji, mencari dan memperbaiki area-area dimana kriteria finansial konvensional dan kriteria lingkungan bertentangan.Mencoba cara-cara dimana system keberlanjutan dapat dinilai dan digabungkan denganorganisasi.

Berdasarkan pendapat diatas bisa dijelaskan bahwa akuntansi lingkungan adalah aktivitas jasa yang memiliki peranan untuk menyediakan informasi akuntansi yang dapat dipengaruhi oleh respon perusahaan terhadap masalah yang mengancam tempat kelangsungan hidup manusia dan mahkluk hidup lainnya. 


\subsubsection{Tujuan Akuntansi Lingkungan}

Akuntansi lingkungan atau "environmental accounting" menurut Djogo (2009:51) adalah istilah umum yang bersangkutan dengan biaya lingkungan terhadap setiap praktek akuntansi baik di lembaga pemerintah maupun di perusahaan. Biaya tersebut merupakan hasil dari akibat segala kegiatan perusahaan yang bersangkutan yang berkaitan dengan lingkungan. Pada dasarnya akuntansi lingkungan memang berkutat pada biaya pengembangan atau perawatan lingkungan khususnya pada perusahaan atau lembaga yang fokus utama pekerjaan mereka berhubungan dengan lingkungan.

\subsubsection{Pentingnya Akuntansi Lingkungan}

Biaya lingkungan merupakan salah satu beberapa tipe biaya yang dikorbankan seperti halnya perusahaan memberikan barang dan jasa kepada konsumen. Sebuah keunggulan di sektor bisnis yang agresif dengan menyalahgunakan potensi di industri sektor bisnis hijau.Dhruv Sabharwal (2016:1). Kinerja lingkungan merupakan salah satu dari beberapa ukuran penting tentang keberhasilan perusahaan.

\subsubsection{Fungsi dan Peran Akuntansi Lingkungan}

Pentingnya penggunaan akuntansi lingkungan bagi perusahaan atau organisasi lainnya dijelaskan dalam fungsi dan peran akuntansi lingkungan. Fungsi dan peran tersebut dibagi kedalam dua bentuk. Fungsi pertama disebut dengan fungsi internal dan fungsi kedua disebut fungsi eksternal (Ikhsan 2008:18).

\subsubsection{Manfaat Akuntansi Lingkungan}

Pengambilan keputusan organisasi dapat menggunakan arus informasi fisik dan informasi biaya yang disediakan oleh akuntansi manajemen lingkungan dalam membuat keputusan- keputusan yang berdampak pada kinerja keuangan dan lingkungan organisasi. Penting untuk dicatat bahwa, ketika akuntansi manajemen lingkungan mendukung pengambilan keputusan internal, penerapan akuntansi lingkungan tidak menjamin setiap tingkat kinerja keuangan atau lingkungan tertentu.Bagaimanapun juga, karena organisasiorganisasi dan program-program mempunyai sasaran tentang pengecilan biaya-biaya, terutama biaya-biaya lingkungan yang memperkecil dampak lingkungan, akuntansi manajemen lingkungan menyediakan satu himpunan penting informasi untuk mencapai tujuan.

\subsubsection{Akuntansi Biaya Lingkungan}

Biaya lingkungan adalah biaya yang dikeluarkan perusahaan berhubungan dengan kerusakan lingkungan yang ditimbulkan dan perlindungan yang dilakukan. Biaya lingkungan mencakup baik biaya internal (berhubungan dengan pengurangan proses produksi untuk mengurangi dampak lingkungan) maupun eksternal berhubungan dengan perbaikan kerusakan akibat limbah yang ditimbulkan (Susenohaji, 2002).

Pencatatan untuk mengelola segala macam yang berkaitan dengan limbah sebuah perusahaan didahului dengan perencanaan yang akan dikelompokkan dalam pos-pos tertentu sehingga dapat diketahui kebutuhan riil setiap tahunnya. Pengelompokkan dalam tahap analisis lingkungan ruang lingkupnya berbeda. Ada PSAK yang menaungi perusahaan yang terdaftar di BEI. SAK yang menaungi perusahaan kecil dan menengah yang tidak terdaftar di BEI. PSAP yang menaungi lembaga pemerintahan. Berhubung penelitian ini obyeknya adalah rumah sakit swasta tapi mengacu pada peraturan PSAP. Bagaimana yang sudah ditentukan dalam Pernyataan Standar Akuntansi Pemerintahan (PSAP) No. 1 tahun 2010 (Hadi, 2012:37).

\section{METODE PENELITIAN}

Jenis penelitian kualitatif sesuai dengan tujuan dari penelitian ini. Tujuan kualitatif menurut Sahlan (2012) adalah untuk memahami fenomena atau gejala sosial dengan menitik beratkan pada gambaran yang lengkap tentang fenomena yang di kaji daripada merincinya 
menjadi variabel-variabel yang saling terkait. Dimana tujuan tersebut sejalan dengan tujuan dari penelitian yang akan dilakukan. Tujuan dari penelitian ini adalah untuk mengetahui bagaimana penerapan akuntansi lingkungan di perusahaan jasa yang berpotensi menghasilkan limbah dari kegiatan operasionalnya.

Penelitian ini juga termasuk dalam penelitian studi kasus (case study), karena penelitian hanya berfokus terhadap penerapan akuntansi lingkungan disalah satu perusahaan. Arikunto (2005:41) menyebutkan penelitian kasus sebagai suatu penelitian yang dilakukan secara intensif, terinci dan mendalam terhadap suatu organisai, lembaga atau gejala tertentu. Ditinjau dari segi keluasan wilayah penelitian, studi kasus hanya dilakukan pada wilayah yang sempit, akan tetapi dengan sifat yang lebih mendalam. Lokasi penelitian dilaksanakan di Rumah Sakit Pancaran Kasih Manado. Waktu penelitian dilaksanakan selama dua bulan.

Dalam penelitian ini penulis menggunakan Data kualitatif yang bersifat deskriptif, untuk mengetahui atau menggambarkan keyataan dari kejadian yang di teliti sehingga memudahkan penulis untuk mendapatkan data yang objektif dalam rangka memahami Analisis Penerapan Akuntansi Manajemen Lingkungan. Data kualitatif yang digunakan dalam penelitian ini yaitu berupa gambaran umum objek penelitian dan data tentang Analisis Penerapan Akuntansi Lingkungan Terhadap Biaya Operasional Pengelolahan Limbah di Rumah Sakit Pancaran Kasih Manado.

Metode Analisis data yang digunakan dalam penelitian ini adalah metode analisis kualitatif deskriptif, yaitu peneliti mendeskripsikan hasil temuannya yang berasal dari datadata yang terkumpul melalui proses observasi di obyek penelitian yang kemudian akan diperbandingkan dengan metode penerapan akuntansi lingkungan secara teori yang selama ini berkembangdikalangan akademik. Peneliti kemudian menganalisis kesesuaian metode akuntansi biaya lingkungan yang diperbandingkan secara setahap demi tahap dalam penerapan akuntansi lingkungan tersebut pada masing-masing metode dengan analisis deskripsi komparatif yang diinterpretasikan atas dasar data yang ada.

Sebelum menjabarkan hasil temuan yang didapat peneliti selama penelitian kedalam narasi yang bersifat kreatif dan mendalam. Peneliti melakukan serangkaian prosedur analisis data. Serangkaian prosedur analisis data dilakukan untuk mendapatkan hasil penelitian yang komponen melalui serangkaian proses sistematis. Prosedur analisis data dalam penelitian ini meliputi:

1. Mengumpulkan dan menganalisa data yang telah diperoleh yaitu dari proses definisi, pengakuan, pengukuran, penilaian, penyajian dan pengungkapan dengan cara membandingkan antara data hasil wawancara dengan data dokumentasi perusahaan yang berupa data laporan keuangan perusahaan, laporan atau data produksi, dan pedoman kebijakan perusahaan untuk pengolahan limbahnya. Data yang diperoleh dari wawancara, observasi, maupun analisis dokumen diverifikasi melalui perbandingan antara data yang diperoleh dengan metode-metode tersebut. Tujuan dilakukan langkah ini adalah untuk mengetahui dan memastikan apa saja biaya yang dikeluarkan oleh perusahaan dan bagaimana perlakuan akuntansi atas biaya pengolahan limbah menyangkut definisi, pengakuan dan pengukuran di dalam laporan keuangan rumah sakit.

2. Hasil dari analisa tersebut selanjutnya akan diperbandingkan dengan PSAP No. 1 tahun 2010 tentang laporan keuangan akuntansi pemerintahan, di perbandingkan dengan PSAK No.33 tahun 2014 tentang pencatatan akuntansi biaya lingkungan dan juga di bandingkan dengan undang-undang yang mendukung tentang pentingnya menjaga lingkungan. Tujuan dilakukan langkah ini adalah untuk mengetahui kesesuaian atau tidak antara standar yang berlaku dan undang-undang yang ada dengan praktek yang terjadi di rumah sakit.

Memberikan kesimpulan atas hasil pembahasan. Apabila hasil analisa masih banyak 
perbedaan-perbedaan dengan standar dan undang-undang yang ada, maka peneliti akan memberikan saran atau masukan yang diperlukan. Tujuan dilakukannya langkah ini adalah untuk membantu memberi rumah sakit beberapa pilihan untuk lebih mengembangkan praktek perlakuan akuntansi biaya lingkungan di perusahaan tersebut sesuai dengan standar dan undang-undang yang mendukung pada saat ini.

\section{HASIL ANALISIS DAN PEMBAHASAN}

\subsection{Hasil Analisis}

\subsubsection{Limbah Operasional RSU. Pancaran Kasih GMIM}

Aktifitas rumah sakit yang berhubungan dengan medis tentunya banyak sekali menghasilkan limbah-limbah B3 atau limbah berbahaya. Dimana limbah B3 perlu penanganan khusus sebelum membuangnya.

Limbah yang di hasilkan dari kegiatan rumah sakit terdapat dalam bentuk cair, dimana dia terbagi atas 2 bentuk:

1. Limbah Cair Infeksius

Limbah Cair nfeksius adalah limbah yang berkaitan dengan bekas operasi pasien dan juga limbah laboratorium. Limbah ini dapat menjadi sumber penyebaran penyakit pada petugas, pasien, pengunjung maupun masyarakat sekitar.

2. Limbah Cair Non-Infeksius

Limbah Cair Non-Infeksius adalah limbah yang berasal dari hasil MCK di Toilet Rumah Sakit, dari Toilet Pasien sampai Toilet Umum.

\subsubsection{Proses Pengelolahan Limbah RSU. Pancaran Kasih GMIM}

Proses pengelolahan limbah cair bias di katakana lebih rumit di banding dengan pengelolahan limbah padat. Dimana proses pengelolahan limbah cair melewati beberapa proses. Di RSU Pancaran Kasih GMIM sendiri proses pengelolahan limbahnya melewati beberapa proses :

1. Membuang pada tempatnya

2. Pretreatmen

3. Great Chamber

4. Anaerobic Biofilter

5. Reaktor Biofilter

6. Filter Pump

7. Post Treatment

8. Sinar UV

9. Kolam Percobaan

10. System Colination

11. Output

\subsubsection{Deskripsi Manajemen Lingkungan RSU. Pancaran Kasih GMIM}

Proses pengelolahan limbah cair bias di katakan lebih rumit di banding dengan pengelolahan limbah padat. Dimana proses pengelolahan limbah cair melewati beberapa proses. Di RSU Pancaran Kasih GMIM sendiri proses pengelolahan limbahnya melewati beberapa proses.

Penggambaran pengambilan keputusan dari suatu perusahaan itu tergantung dari perusahaan itu sendiri untuk menggunakan informasi yang di hasilkan dari informasi biaya lingkungan. Begitupula dengan sebuah instansi pemerintahan yang bergerak di bidang jasa kesehatan yaitu rumah sakit. Biaya lingkungan merupakan biaya yang di keluarkan perusahaan untuk mencegah akan terjadinya kerusakan lingkungan sekitar atau biaya yang di keluarkan jika terjadi kerusakan lingkungan yang di sebabkan oleh limbah suatu perusahaan maupun instansi. Hal tersebut juga di ungkapkan oleh Bapak Lexi selaku kepala bagian pengelolahan limbah, bahwa: 
"biaya lingkungan timbul sebagai biaya-biaya atas operasional RSU Pancaran Kasih GMIM yang bertujuan untuk mencegah terjadinya kerusakan di lingkungan sekitar rumah sakit. Biaya lingkungan juga di keluarkan jika lingkungan di sekitar rusak ataupun tercemar akibat limbah dari operasional rumah sakit ini sendiri baik dampak untuk lingkungannya maupun dampak sosial akibat kegiatan operasional rumah sakit”.

Dalam kegiatan operasional rumah sakit yang menghasilkan limbah cair, padat maupun gas, RSU Pancaran Kasih GMIM menggunakan Instalasi Pengelolahan Air Limbah (IPAL) yang di bawahi langsung oleh bagian petugas IPAL. Hal ini menjadi tanggung jawab petugas IPAL agar pengelolahan limbah dapat sesuai standart rumah sakit yang berpacu pada UU yang berlaku di Indonesia tentang lingkungan hidup.

\subsubsection{Pengakuan Biaya Lingkungan RSU Pancaran Kasih GMIM}

Pengakuan berhubungan dengan masalah transaksi akan di catat atau tidak ke dalam sistem pencatatan, sehingga pada akhirnya transaksi tersebut akan berpengaruh pada laporan keuangan rumah sakit. RSU Pancaran Kasih GMIM mengakui elemen tersebut sebagai biaya apabila sudah memberikan manfaat bagi pihak rumah sakit. Hal ini sesuai dengan yang di ungkapkan oleh Ibu Ivana selaku Kepala Bagian Akuntansi bahwa:

"alokasi biaya pengelolahan limbah di ambil dari anggaran biaya tahunan dan baru bisa di sebut biaya apabila sudah di gunakan dan memberi manfaat pada periode ini, meskipun kas belum di keluarkan. Seperti pembayaran gaji, upah ataupun biaya listrik".

Menurut keterangan dari Ibu Ivana tersebut selaku Kepala Bagian Akuntansi, di jelaskan baru bisa di sebut biaya apabila sudah di gunakan dan memberi manfaat, meskipun kas belum di keluarkan. Itu artinya pihak rumah sakit menggunakan metode pengakuan akrual basis, dimana pengakuannya terjadi saat pihak rumah sakit sudah bermanfaat.

\subsubsection{Pengukuran Biaya Lingkungan RSU Pancaran Kasih GMIM}

RSU Pancaran Kasih GMIM dalam mengukur biaya-biaya lingkungan (dalam hal biaya pengelolahan limbah) menggunakan harga perolehan berdasarkan biaya yang di keluarkan dan di ambil dari realisasi anggaran periode sebelumnya. Hal ini di dasarkan atas penyataan dari Bapak Lexi yang menyatakan bahwa :

"dalam mengukur semua biaya limbah, rumah sakit menggunakan harga perolehan.

Sesuai yang sudah di keluarkan dan mengacu pada hasil realisasi anggaran periode sebelumnya karena hal itu lebih akurat. Klo berbeda pun, nanti tidak akan jauh bedanya dengan realisai anggaran pada periode ini ".

RSU Pancaran Kasih GMIM dalam mengukur biaya yang di keluarkan yaitu dengan menggunakan harga perolehan yang mengacu pada realisasi biaya pada periode sebelumnya dan sebesar biaya yang di keluarkan.

\subsection{Hasil Pembahasan}

Rumah Sakit Pancaran Kasih GMIM sudah melakukan proses Pengakuan, Pengukuran, Pencatatan, Penyajian, dan juga Pengungkapan seperti halnya yang sudah di jelaskan pada Standar Akuntansi Pemerintahan Per 13 Juni 2010. SAP No. 1 tersebut menjelaskan tentang penyajian laporan keuangan. Dimana Rumah Sakit Pancaran Kasih GMIM mengakui biaya-biaya lingkungan yang terjadi sebagai biaya operasional. Pengakuan tersebut menggunakan metode akrual basis. Hal ini seperti yang sudah ada pada peraturan Pemendagri No. 64 Tahun 2013 tentang penerapan akuntansi berbasis full akrual di pemerintahan pada tahun 2017. Pengukuran yang di lakukan oleh pihak Rumah Sakit Pancaran Kasih GMIM menggunakan harga perolehan yang di keluarkan oleh pihak rumah sakit dan berdasarkan realisasi anggaran di tahun sebelumnya atau biasa di sebut Historical Cost. Dengan begitu anggaran yang di keluarkan pada periode ini tidak jauh berbeda dengan realisasi tahun sebelumnya. Rumah Sakit Pancaran Kasih GMIM menyajikan biaya 
lingkungan dengan memasukkan komponen-komponen biaya lingkungan mereka pada laporan keuangan umum. Mencatat biaya-biaya lingkungan secara keseluruhan yakni dalam lingkup satu ruang rekening secara umum bersama rekening lain yang serumpun. Biaya-biaya yang serumpun tersebut disisipkan dalam sub-sub unit rekening biaya tertentu dalam laporan keuangannya. Rumah Sakit Pancaran Kasih GMIM sudah mengungkapkan adanya pengelolahan limbah pada Catatan Atas Laporan Keuangan mereka namun belum mengungkapkan secara khusus.

\section{KESIMPULAN DAN SARAN}

\subsection{Kesimpulan}

Berdasarkan pembahasan mengenai penerapan akuntansi manajemen lingkungan dan bagaimana perlakuan biaya dalam laporan keuangan di RSU Pancaran Kasih GMIM,maka dapat di simpulkan sebagai berikut:

1. Rumah Sakit Pancaran Kasih GMIM sudah menerapkan akuntansi manajemen lingkungannya. Biaya lingkungan tersebut di masukkan pada biaya belanja pegawai langsung dan belanja pegawai tidak langsung.

2. Rumah Sakit Pancaran Kasih GMIM sudah melakukan proses Pengakuan, Pengukuran, Pencatatan, Penyajian, dan juga Pengungkapan seperti halnya yang sudah di jelaskan pada Standar Akuntansi Pemerintahan Per 13 Juni 2010. SAP No. 1 tersebut menjelaskan tentang penyajian laporan keuangan. Dimana Rumah Sakit Pancaran Kasih GMIM mengakui biaya-biaya lingkungan yang terjadi sebagai biaya operasional. Pengakuan tersebut menggunakan metode akrual basis. Hal ini seperti yang sudah ada pada peraturan Pemendagri No. 64 Tahun 2013 tentang penerapan akuntansi berbasis full akrual di pemerintahan pada tahun 2017. Pengukuran yang di lakukan oleh pihak Rumah Sakit Pancaran Kasih GMIM menggunakan harga perolehan yang di keluarkan oleh pihak rumah sakit dan berdasarkan realisasi anggaran di tahun sebelumnya atau biasa di sebut Historical Cost. Dengan begitu anggaran yang di keluarkan pada periode ini tidak jauh berbeda dengan realisasi tahun sebelumnya. Rumah Sakit Pancaran Kasih GMIM menyajikan biaya lingkungan dengan memasukkan komponen-komponen biaya lingkungan mereka pada laporan keuangan umum. Mencatat biaya-biaya lingkungan secara keseluruhan yakni dalam lingkup satu ruang rekening secara umum bersama rekening lain yang serumpun. Biaya-biaya yang serumpun tersebut disisipkan dalam sub-sub unit rekening biaya tertentu dalam laporan keuangannya. Rumah Sakit Pancaran Kasih GMIM sudah mengungkapkan adanya pengelolahan limbah pada Catatan Atas Laporan Keuangan mereka namun belum mengungkapkan secara khusus. Namun hal itu tidak melanggar Standar Akuntansi Pemerintahan yang ada, dikarenakan akuntansi lingkungan hanya bersifat sukarela

3. Rumah Sakit Pancaran Kasih GMIM sudah melakukan pengelolahan limbah mereka dengan baik. Rumah Sakit Pancaran Kasih GMIM yang sudah mengeluarkan biaya- biaya lingkungannya. Hal itu sejalan dengan Undang-undang No. 32 Tahun 2009 tentang perlindungan dan pengelolahan lingkungan hidup dan Undang-Undang No. 25 Tahun 2007 tentang penanaman modal. Dengan di keluarkannya biaya-biaya tersebut, Rumah Sakit Pancaran Kasih GMIM sudah turut melakukan perlindungan dan menjaga lingkungan hidup seperti yang ada pada kedua Undang-Undang tersebut..

\subsection{Saran}

Peneliti menyadari bahwa dari hasil penelitian yang telah disimpulkan diatas masih terdapat banyak kekurangan dan belum sempurna, namun peneliti mencoba memberikan saran untuk perusahaan agar kedepannya jauh lebih baik lagi yaitu sebagai berikut: 
1. Diharapkan bagi pihak rumah sakit untuk mengelola limbah cair yang berkaitan dengan bekas operasi pasien dan juga limbah laboratorium. Limbah, di karenakan limbah cair tersebut telah sedikit merembes ke pemukiman masyarakat Agar segera pemperbaiki selokan-selokan yang ada disekitar rumah sakit. Limbah ini menjadi sumber penyebaran petugas, pasien, pengunjung maupun masyarakat sekitar.

2. Sedangkan bagi peneliti selanjutnya yang membahas akuntansi manajemen lingkungan, hendaknya menganalisis dari sisi laporan keuangan rumah sakit yang berdasarkan Standar Akuntansi Keuangan (SAK).

\section{DAFTAR PUSTAKA}

Arikunto, S. 2005. Manajemen Penelitian. Cetakan Ketujuh. Edisi Revisi. PT Rineka Cipta. Jakarta

Djogo. 2006. Akuntansi Lingkungan. Makalah 7 Pebruari 2006.

Hadi, Nor. (2012). Corporate Social Responsibility.Yogyakarta. Graha Ilmu

Indonesia, I. A. (2009). Pernyataan standar akuntansi keuangan. Salemba Empat. Jakarta.

Ikatan Akuntan Indonesia. 2009. Standar Akuntansi Keuangan. Jakarta: Penerbit Salemba Empat.

Ikhsan, Arfan. 2008. Akuntansi Lingkungan. Yogyakarta : Graha Ilmu.

Munawir, S. (2002). Akuntansi Keuangan dan Manajemen. Edisi Revisi. Penerbit BPFE. Yogyakarta.

Rudianto. 2009. Pengantar Akuntansi. Erlangga. Jakarta

Sahlan. 2012. Desain Pembelajaran Berbasis Pendidikan Karakter. Yogyakarta: ArRuzz Media.

Solihin, Ismail. (2009). Corporate Social Responsibility from Charity to Sustainability. Jakarta: Salemba Empat.

Susenohaji. 2002. Enviromental Management Accounting (EMA) Memposisikan kembali biaya lingkungan sebagai informasi strategis bagi manajemen

Suwardjono. 2005. Teori Akuntansi :Perekayasaan Pelaporan Keuangan. Edisi Ketiga. BPFE, Yogyakarta. 